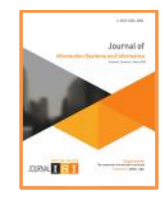

Vol. 3, No. 2, June 2021 e-ISSN: 2656-4882 p-ISSN: 2656-5935

http://journal-isi.org/index.php/isi

Published By DRPM-UBD

\title{
The Role of Information Systems Capabilities as A Driving Force in Enhancing the Organizational Performance
}

\author{
Laith Tashtoush \\ Faculty of Economics and Administrative Sciences, Business Administration Department, Near \\ East University, ZIP: 99138 Nicosia/TRNC, Mersin 10 - Turkey.
} Email: laith.tashtoush@,neu.edu.tr

\begin{abstract}
The literature supports that information systems improve the effective performance of any organization and gain a competitive advantage for their success in the business environment. Therefore, the scholars should do more studies that focus on how to enhance organizational performance to let corporations to sustain their competitive advantage. This study aims to empirically investigate the mediating role of competitive advantage with information systems capabilities and organizational performance among managers and heads of the departments working at Jordanian industrial corporations. Data were gathered using a questionnaire. The population of the study consisted of managers and heads of the departments working in 20 Jordanian industrial corporations. A total of 235 employees participated in the study. Data analysis involved the computation of descriptive statistics, as well as structural equation modelling, factor analysis, regression and correlation analysis. The study results showed that information systems capabilities, competitive advantage, and organizational performance were statistically significant. In addition, the result revealed that information system capabilities through competitive advantage influence organizational performance. The study model developed to provide the relationships of information systems capabilities through competitive advantage that can be used by Jordanian industrial corporations as evidence of a positive impact on organizational performance of managers and heads of departments in their corporations.
\end{abstract}

Keywords: Information Systems Capabilities, Competitive Advantage, Organizational Performance, Industrial Corporation, Jordan.

\section{INTRODUCTION}

Information, along with technological development, is a critical component of industrial business, although in the 21 st century, it has become a key factor [1]. Successful implementation of the information system (IS) is described by organizations as a critical component of efforts to promote and achieve their goals. 
In addition, the use of information technology and the development of a competitive advantage (CA) have produced positive and important results [2], [3].

The importance of IS has increased recently and has become a vital necessity for all Jordanian public and private companies due to the increased complexity of the companies' functions [4]. Also, the rapid development of technology and the development of production methods and tools and methods of communication and information transmission, they have all worked to further complicate the administrative and productive process. So, they have facilitated and simplified the work procedures of corporations and improved their performance [5]. The work of the strategic perspective in modern management on the need for continuous search of managers areas to improve the effectiveness of the performance of their corporation's efficiency and increase their productivity and quality of output [6], [7]. Due to the environmental factors and administrative developments, the need of third world countries for modern IS depends on automated computers. Especially since there is a strong demand for the acquisition of modern technological devices, due to the technical capabilities available in them [8].

Organizational performance (OP) is one of the most important constructs in management research [9], [10]. Where OP was and still is "an endless research question with many studies considering it as their dependent construct" [11]. Increased research into OP has led to different and partly contradictory definitions and theories [12], [13]. OP is difficult to define because there are many different perspectives on performance, and also the indicators of performance are complex [14]-[17]. Although, many authors have different definitions of performance [18], [19]. OP is the measure of progress of an organization, which is an analysis of the performance of the institution compared to the objectives [20]-[25]. According to Venkatraman \& Ramanujam and Yunis et al., [10], [26] there are three performance levels within corporations. These are classified as financial performance, work performance and organizational effectiveness, although the latter is later known as OP [27], [28]. But many researchers' express OP as referring to an organization's index to measure its achievement [29]-[31].

CA definition of corporations about their ability to meet different consumer desires by imparting items and offering of suitable excellent through which access to international markets [32]-[35], [35], [36]. The ability to produce items and services of right exceptional and the proper fee and on the right time, and that means meet the needs of consumers more efficiently than different centers [35]. Facing various external corporations and internal challenges and multiple other, for the internal level, there are changes in the composition of human resource and their qualifications and aspirations and ambitions and problems [37], [38]. There is an urgent need to change the philosophy of corporations, mission and vision, and corporation structures and processes. There is a crisis in the leadership of 
Vol. 3, No. 2, June 2021

p-ISSN: 2656-5935 http://journal-isi.org/index.php/isi e-ISSN: 2656-4882

many of these corporations, its managers underline their ancient philosophies stemming from old theories and practices [39]-[41].

The importance of CA in maximizing the use as much as possible of the features provided by the global economy and to minimize its disadvantages [42], [43]. This indicates that the global CA of a report that small states are better able to take advantage of the concept of CA of the big countries. Also, gives the CA of small countries corporations an opportunity to get out of small market limited to the spaciousness of the global market [44]. In this case, these small and developing countries have become forced to confront this system, as one of the challenges of the twenty-first century.

IS are currently among the main topics of concern to managers in different corporations [45]. It consider as the most important and widespread strategic resource as it meets the urgent needs that raise the level of productivity of corporations and supporting them to achieve the CA [7], [46]. The importance of this study stems from the fact that the success of industrial corporations in performing their work and activities efficiently and effectively depends on the availability of sound information and the ease of flow in time, accuracy and cost. Also, the efficient IS has become a prerequisite for survival and not just to improve performance [47].

Since industrial corporations are part of the global environment affected, they are undergoing various environmental transformations and changes, affecting both public and private corporations [48]-[50]. Therefore, Jordanian corporations requires to adapt to these rapid transformations and changes in order to ensure their survival and continuity. Jordanian industrial corporations operate in a changing environment, which increases uncertainty about the conditions in which they operate [51]. This means that they are not more likely to operate efficiently and effectively and therefore do not achieve a CA over other corporations [52]. Over the past few decades, industrial have been using ISC more to manage their OP [53]. Jordanian industrial began to electronically automate many of processes by introducing specialized ISC to reduce the routine transaction and traditional activities and to deal with the complex transformational ones. Therefore; to increase the effectiveness of ISC, Jordanian industrial are becoming more dependent on ISC [54]. At the functional level, ISC can keep track of employees', applicants', and contingent workers' conditions, demographics, performance appraisal, professional development, payroll, recruitment, and retention [55]. Thus, Jordanian industrial today's are becoming heavily dependent on ISC to raise the effectiveness of OP and have a CA [56]. Every Jordanian industrial nowadays considered ISC as an integral part of any organization functions. It's noted that more and more organizations are developing ISC which can help the Jordanian industrial to achieve the goals in a timely manner and increase their OP, which can help organizations make more strategic decisions by benefiting from ISC and gain 
a CA [57], [58]. This study came to identify the key applications for ISC and its impact on OP by taking CA as a mediator in the Jordanian industrial corporations. Therefore, there is a paucity of research on the ISC and their impact on CA and $\mathrm{OP}$ in Jordanian industrial which has a significant gap that not evidently clear in the literature. Therefore, this study aims to empirically examining the mediating role of CA with ISC and OP amongst managers and head of departments working at Jordanian industrial corporations.

\section{THEORETICAL FRAMEWORK AND HYPOTHESES DEVELOPMENT}

\subsection{Information Systems Capabilities and Organizational Performance}

Recently, the influence of ISC on OP has been a topic of interest to many researchers. There are fewer reports on the industrial sector exploring the relationship between ISC and OP [62]-[66], [66]-[68]. Also, Turel et al. [69] consider that the study of the effect of the ISC on OP should be the subject of future efforts. However, despite the fact that some studies have found that the ISC has a major influence on OP, others have provided conflicting findings that are difficult to compare, given the variability of both the research targets and the methods and techniques used. This may explain why few research papers have addressed the fundamental mechanisms that relate output to ISC [63], [70]. Therefore, this study proposes to analyze the relationship between the ISC and OP. In this regard, few studies have established the existence of a direct relationship between those components. The scarcity of works examining this relationship is explained by the difficulty of interpreting the contribution of these capabilities to OP, especially in measuring that output [53], [71]-[77]. Accordingly, the following hypothesis is posited:

\section{$\boldsymbol{H}_{1}$ : Information system capabilities positively influence organizational performance.}

\subsection{Competitive Advantage and Organizational Performance}

Ma, Morgan et al., Potjanajaruwit and Ong et al. [78]-[81] stated that although there is a complex connection between CA and OP but they are two special terms and have a high correlation between each other. Also, Rose et al. [82] suggested that OP from a resource-based view (RBV) is as vital as possible as it is which used as a conceptual guideline for a business organization to enhance the position of differential advantage. OP is also increased across devices and manipulated internal resources known to corporations with the use of competencies with which the company's excellence can be enhanced by using these qualities. The RBV is a basis for the CA which theorizes the importance of resources and capabilities to gain CA as an end to a greater OP [83]. In the study that conducted by Raduan et 
Vol. 3, No. 2, June 2021

p-ISSN: 2656-5935 http://journal-isi.org/index.php/isi

e-ISSN: 2656-4882

al. and Khan et al. [84], [85] concluded that there is a positive relation between CA and $\mathrm{OP}$ which means that CA is able to significantly predict the variance in the OP. Allen \& Helms, Ferreira et al. and Teeratansirikool et al. [86]-[88] suggested that those who established businesses that choose CA produce better performance than their competitors. Baker \& Sinkula and Escandón-Barbosa \& Hurtado-Ayala [89], [90] emphasized that the key role that innovation plays in enhancing the organization CA has a direct and positive impact on its OP. Therefore, a positive relationship between CA and OP can be proposed as following:

\section{$\boldsymbol{H}_{2}$ : Competitive advantage positively influence organizational performance.}

\subsection{The Mediating Role of Competitive Advantage between Information System Capabilities and Organizational Performance}

Breznik [91] found that there has been significant attention in recent years to the possibility that ISC could contribute to an OP and help them achieve CA. The organizational structure is also re-examined and adapted to strengthen OP through shared capital, creativity, and cooperation across organizational boundaries, while ISC is being adopted [92], [93]. It is worth noting that while ISC may contribute to the CA of an entity, many prerequisites seem to exist. Chiu \& Yang [94] indicated that the best OP could be accomplished when ISC investments are matched within the corporate plan with the internal resources and organizational processes. This means that the value of using ISC in general is closely related to the use of organizational resources. Tarute \& Gatautis [95] argued that investments in the use of ISC by most organizations are hindered by high financial investment costs, the lack of infrastructure needed to support ISC, the lack of trained personnel, and technology advancement without sufficient training for users. This study develops the following hypothesis on the basis of all the studies listed above:

\section{$\boldsymbol{H}_{3}$ : Competitive advantage mediates the relationship between information systems capabilities and organizational performance.}

\subsubsection{Human Resources}

Human capital is the core elements that push businesses to have a CA, where HR is applied in an efficient and effective way to control employee skills, skill, and knowhow to impact a company's strategic goal achievement [96]. Hamadamin \& Atan and Wright \& McMahan [97], [98] suggested that the system that HR applies to achieve organizational objectives was proposed. HR also provides a connection between the requirements of the company and the activities of a corporation that unites and guides employees in compliance with the strategies of the company to achieve a CA (Findiklı et al., 2015; Greer, 2001; Greer, 2019). Emeagwal \& Ogbonmwan [55] believed that HR would allow a company to have a CA. In addition, $\mathrm{HR}$ is seen as a significant resource that must be deployed with other 
resources to boost the company's efficiency. Greer and Findikli (Greer, 2019; Findiklı et al., 2015) claimed that HR should be seen as a mechanism to raise, promote and decrease employee turnover to ensure the corporation's successful implementation. Huang \& Huang [102] proved that a significant influence of HR is found on positive corporation outcomes.

Kuncoro \& Suriani and Mahdi \& Almsafir (Kuncoro \& Suriani, 2018; Mahdi \& Almsafir, 2018) suggested that the implementation of strategy to create value-added that is not concurrently being implemented with the aid of any other corporations in the marketplace is said to be a CA. In this case, corporation needs to efficaciously enforce the strategy that will enhance their performance to have a CA in the marketplace. Therefore, most corporations formulate a CA to deal with many resources to have the ability to generate a CA. Covin \& Lumpkin [105] argued that in a swiftly changing global marketplace in which $\mathrm{CA}$ is assumed to not be sustainable, HR are located to be an important source of failing in achieving and sustaining a CA, while others achieve it. Meanwhile, there is a need to examine the direct influence of the bundles of HR on the sustainable CA. According to the previous discussion, the following hypothesis is formulated:

\section{$\boldsymbol{H}_{3} \mathbf{a}$ : Competitive advantage mediates the relationship between human resource and organizational performance.}

\subsubsection{Software}

The use of IS for CA involve structure that hyperlink a corporation to providers, distribution channels, or clients. These structures use ISC in corporation to enhance the overall performance or to enhance the relationships amongst corporations. The main objective of ISC software is to create value-added by using the Internet to connect different corporations with others through IS applications. Also, software creates higher relationships between clients, setting the establishment of globalization and growth the CA of corporations. ISC software is designed to meet the needs of corporation and added a specific improvement process [106]. These improvements will lead corporations to have a new modification and versions of their software [107].

ISC software follow the market requirements where corporations consider the important standards for solving the identified problems that may occur. Furthermore, to gain a CA from ISC software process the corporation must be monitored and evaluated their software to determine its stability continuously [108]. Lucas \& Smith and Chaudhry [109], [110] recommends that to have a better CA the corporations need to improve the performance of their software. Evolutionary software maintenance has flourished because of the ease of adding new functionality to the system but at the same time it puts an additional risk [111], [112]. Therefore, the following hypothesis is posited: 
Vol. 3, No. 2, June 2021

p-ISSN: 2656-5935 http://journal-isi.org/index.php/isi e-ISSN: 2656-4882

$\boldsymbol{H}_{3} \boldsymbol{b}$ : Competitive advantage mediates the relationship between software and organizational performance.

\subsubsection{Hardware}

Bevilacqua et al. [113] stressed the significance of ISC to discover the route how to manage and organize the result ISC based on computer data. Mikalef \& Pateli and Bhatt \& Grover [114] [115] suggested that ISC process can be divided into programs and procedures, computer programs implemented by the hardware and the procedures implemented by users. Chae et al. and Santhanam \& Hartono [116] [117] proposed that the users are the most important component of the ISC hardware. These components are executed and controlled by the hardware and users [7], [46].

According to Han \& Kim and Jun \& Kang [118], [119], the investment in IS is substantially linked to the use of ISC. Fang et al. and Forman [120] [121] noted that a higher degree of use of ISC is difficult and can entail changes in company processes. Since the organization wants to use ISC to incorporate and turn its business model into its business operations, substantially more ISC investment will be required [122] [123]. In order to keep up with and distinguish better from their rivals, businesses need to invest in ISC [124] [125]. Several studies have also indicated that the ISC expenditure has enhanced the efficiency of the sample firms, even by benefiting customers from increased productivity (Kim et al., 2008; Teo, 2007; González-González \& Nogués, 2019; Lu et al., 2019). The research conducted by Kim et al. and González-González \& Nogués [129] [126] It demonstrates that hardware has the ability to produce CA as a significant resource. Budgeting for ISC hardware is also particularly necessary when using CA. In general, the investment in software is substantial and helps to boost and optimize the use of investment in hardware. In addition, there is a need to handle the fitted hardware more efficiently in the case of high-income nations by securing more expertise in terms of internal spending [122] [123]. The greater the ISC expenditure, the better the infrastructure and hardware supported by the company to help the ISC in corporations and achieve the CA [130] [131]. The following hypothesis is proposed in this regard:

\section{$\boldsymbol{H}_{3} \mathbf{c}$ : Competitive advantage mediates the relationship between hardware and organizational performance.}

The RBV claims that ISC is held by corporations, a subset of which helps them to attain CA, and a further subset that contributes to superior long-term OP. RBV empirical OP studies have found variations not only between corporations in the same market, but also within the narrower confines of groups within industries [132]. This indicates that the impact on output of human, firm-specific resources may be important. ISC, CA, and OP are variables that complement each other in 
Vol. 3, No. 2, June 2021

p-ISSN: 2656-5935 http://journal-isi.org/index.php/isi e-ISSN: 2656-4882

this way. A successful ISC would lead the business to have a CA that, in turn, increases its OP. Figure 1 represented the conceptual model of this study.

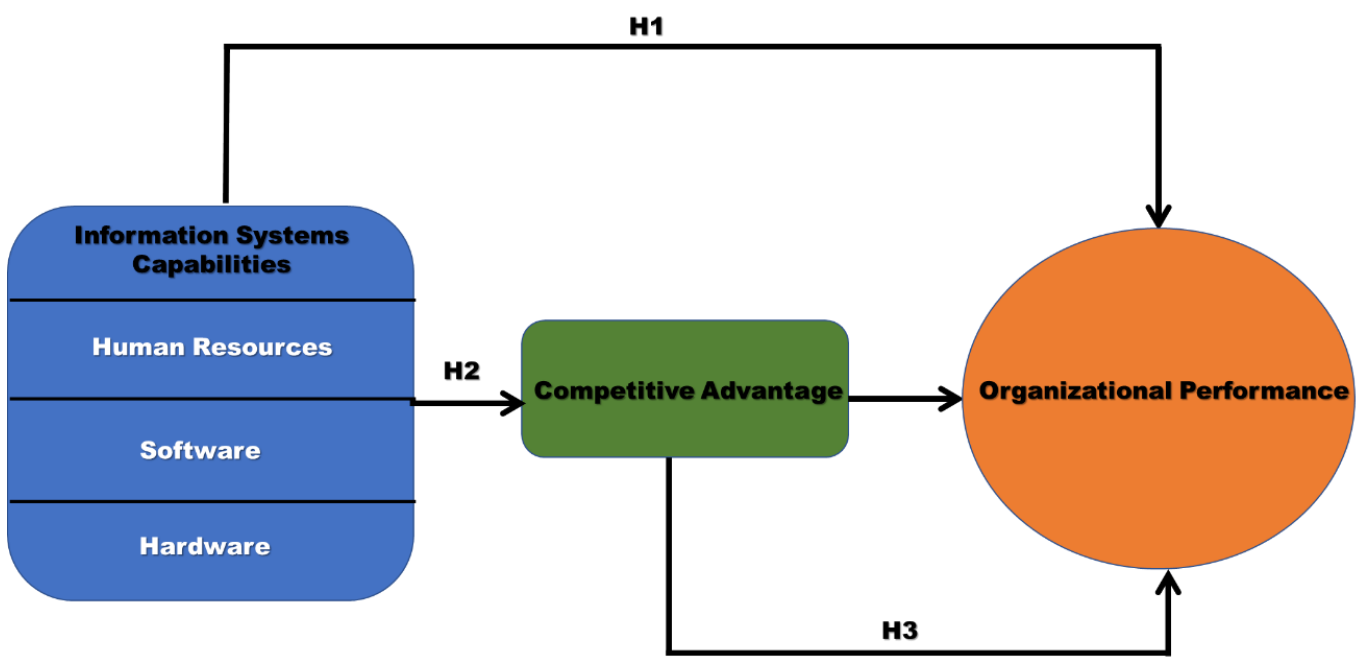

Figure 1 Conceptual Model

\section{METHODS}

\subsection{Study Variables and Instrument}

The questionnaire is divided into three parts and a total of 47 items: demographic information, the Information Systems Capabilities Scale (ISCS), the Competitive Advantage Scale (CAS), and Organizational Performance Scale (OPS). In the demographic questions, there are 5 items (1-5). The ISCS includes 28 items with a standard format Five-Point Likert Scale and divided into three sub-dimensions: human resources, software and hardware. With a Cronbach's alpha of 0.923, human resources are assessed by 14 items (items 6-19). Software with a Cronbach's alpha value of 0.914 is calculated through six items (items 20-25). Hardware is calculated through 7 items (items 26-32) with a Cronbach's alpha value of 0.762 . According to Hair, Black, Babin, \& Anderson [133] the level of Cronbach's alpha needed to achieve reliability and to be an acceptable study is 0.7 , so the Cronbach's alpha values of the 27 items for the ISCS are 0.809 , and this value is considered reliable.

The CAS contains 10 items (items 33-42) with the format of a typical Five-Point Likert Scale. The Cronbach's alpha values of the 10 items for the CAS are 0.826 and these values are also considered reliable. 
Vol. 3, No. 2, June 2021

p-ISSN: 2656-5935 http://journal-isi.org/index.php/isi e-ISSN: 2656-4882

The OPS have 9 items (items 43-51) with the format of a typical Five-Point Likert Scale. The Cronbach's alpha values of 9 items for the CAS are 0.735 , these values are also considered reliable. The Cronbach's alpha value for the present study of 46 items was calculated to be 0.806 , which is considered reliable.

\subsection{Sample and Procedure}

The study population consisted of all managers and department heads working in 65 Jordanian industrial corporations. According to the statistical report of Amman Stock Market for the period 2018-2019, 20 Jordanian industrial corporations were selected as the study sample. Consequently, a total of 250 managers and department heads were randomly selected to participate in the analysis using a convenience sampling method. A questionnaire with a cover letter describing the purpose of the analysis was distributed by hand in the industrial corporations in different work areas. Of the 250 questionnaires distributed, 235 questionnaires were usable for analysis with a response rate of $94 \%$. The data was collected between April 2019 and June 2019. The aim of this study was to meet the ethical values of volunteering, ensure participants' unbiasedness, and respect their right to privacy, anonymity, and self-determination. Participants were introduced to the meaning of the research and its purpose during the study. That is, it was explained that the purpose of the study was to serve Jordanian industrial companies by establishing that the process of information collection and analysis is an important element in the process of decision making and effectiveness, thus CA is achieved. In addition, it was pointed out that participation in the study is voluntary and that the data obtained in the study will be used for research purposes only and will be kept strictly confidential. Finally, the participants' data will be kept confidential and secret.

\section{RESULTS}

\subsection{Demographic Characteristics}

The demographic characteristics collected in this study include 5 different aspects: Gender, age, education level, years of experience, and position. Table 1 summarizes the demographic characteristics of the respondents. The results of the study show that $79 \%$ were male, $84 \%$ were between 30 and 49 years old, $43 \%$ had a college degree, $67 \%$ had 5 to 9 years of experience, and $43 \%$ had a position as a head of department. 
Vol. 3, No. 2, June 2021

p-ISSN: 2656-5935 http://journal-isi.org/index.php/isi e-ISSN: 2656-4882

Table 1 Demographical characteristics

\begin{tabular}{|c|c|c|c|}
\hline Variables & & Frequency & Percent \\
\hline \multicolumn{4}{|l|}{ Gender } \\
\hline & Male & 186 & $79 \%$ \\
\hline & Female & 49 & $21 \%$ \\
\hline & Total & 235 & $100 \%$ \\
\hline \multicolumn{4}{|l|}{ Age } \\
\hline & Less Than 30 & 11 & $5 \%$ \\
\hline & From $30-39$ & 99 & $42 \%$ \\
\hline & From $40-49$ & 98 & $42 \%$ \\
\hline & More than 50s & 27 & $11 \%$ \\
\hline & Total & 235 & $100 \%$ \\
\hline \multicolumn{4}{|c|}{ Educational Level } \\
\hline & Bachelor & 101 & $43 \%$ \\
\hline & Master & 95 & $40 \%$ \\
\hline & PHD & 39 & $17 \%$ \\
\hline & Total & 235 & $100 \%$ \\
\hline \multicolumn{4}{|c|}{ Years of Experience } \\
\hline & Less than 1 year & 7 & $3 \%$ \\
\hline & From 1 - 4 years & 45 & $19 \%$ \\
\hline & From $5-9$ years & 157 & $67 \%$ \\
\hline & 10 years or More years & 26 & $11 \%$ \\
\hline & Total & 235 & $100 \%$ \\
\hline \multicolumn{4}{|l|}{ Position } \\
\hline & General Manager & 25 & $11 \%$ \\
\hline & Unit Manager & 73 & $31 \%$ \\
\hline & Head of Department & 101 & $43 \%$ \\
\hline & Head of Division & 36 & $15 \%$ \\
\hline & Total & 235 & $100 \%$ \\
\hline
\end{tabular}

\subsection{Correlation Analysis}

The results of the correlation analysis showing that all seven constructs were positively correlated with each other with a significance value of 0.01 are presented in Table 2. The correlation coefficient between ISC and CA $(\mathrm{R}=0.454)$ in Jordanian industrial corporations indicates a significant and low positive correlation. However, the correlation coefficient between ISC and OP $(\mathrm{R}=0.471)$ in Jordanian industrial corporations is significant and low positive correlation. The relationship between HR and CA $(\mathrm{R}=0.759)$ is considered to have a significant and high positive correlation. The relationship between HR and $\mathrm{OP}(\mathrm{R}=0.823)$ is considered a significant and high positive correlation. The relationship between HW and CA $(\mathrm{R}=0.744)$ is considered as a high positive correlation. The relationship between HW and OP $(\mathrm{R}=0.757)$ is considered as a significant and high positive correlation. The relationship between $\mathrm{SF}$ and $\mathrm{CA}(\mathrm{R}=0.761)$ is considered as a very high positive correlation. The relationship between SF and 
Vol. 3, No. 2, June 2021

p-ISSN: 2656-5935 http://journal-isi.org/index.php/isi e-ISSN: 2656-4882

OP $(\mathrm{R}=0.729)$ is considered as a significant and high positive correlation. The relationship between CA and OP $(R=0.901)$ is considered a significant and very high positive correlation.

Table 2 Correlation coefficients

\begin{tabular}{ccccccc}
\hline Variable & ISC & HR & HW & SF & CA & OP \\
\hline ISC & 1 & & & & & \\
HR & $.681^{* *}$ & 1 & & & & \\
HW & $.600^{* *}$ & $.795^{* *}$ & 1 & & & \\
SF & $.448^{* *}$ & $.694^{* *}$ & $.769^{* *}$ & 1 & & \\
CA & $.454^{* *}$ & $.759^{* *}$ & $.744^{* *}$ & $.761^{* *}$ & 1 & 1 \\
OP & $.471^{* *}$ & $.823^{* *}$ & $.757^{* *}$ & $.729^{* *}$ & $.901^{* *}$ & 1 \\
\hline
\end{tabular}

ISC, information system capabilities; HR, human resource; HW, hardware; SF, software; CA, competitive advantage; OP, organizational performance.

**, Significant at the 0.01 level (two-tailed), $\mathrm{N}=235$.

\subsection{Factor Analysis}

Hinkin [134] recommended that scientists should utilize exploratory factor analysis (EFA) to decrease the noticed factors to more modest numbers and recognize the connection between them. The author, as suggested by Hair et al. [133], utilized the principal component analysis (PCA) strategy followed by the Promax revolution technique with Kaiser standardization to remove the components by holding items that stacked at 0.4 or more on a solitary item. The Kaiser-MeyerOlkin (KMO) esteem was 0.773 and Bartlett's test was critical at $(\mathrm{P}<0.05)$, which is effectively the sample value required by Kaiser [135].

EFA analysis extracted five different factors explaining $60.06 \%$ of the total variance for Jordanian industrial corporations. HR possessed fourteen items, of which three were deleted, resulting in eleven items that loaded from 0.626 to 0.853 and explained $21.82 \%$ of the total variance. The CA construct had ten items and three items were deleted resulting in the remaining seven items loading from 0.669 - 0.918 the construct explained $13.99 \%$ of the total variance. The construct of SF had six items that loaded between 0.636 - 0.947 and the construct explained $10.09 \%$ of the total variance. The construct of OP had nine items, two of which were deleted, resulting in seven items that loaded between 0.634 to 0.746 and the construct explained $8.02 \%$ of the total variance. The HW had seven items, two items were deleted resulting in five items that loaded between 0.634 to 0.746 and explained $6.14 \%$ of the total variance. Table 3 summarizes the result of the exploratory factor analysis. 
Vol. 3, No. 2, June 2021

p-ISSN: 2656-5935 http://journal-isi.org/index.php/isi e-ISSN: 2656-4882

Table 3 Exploratory Factor Analysis Result

\begin{tabular}{ccccc}
\hline Factors & Items & Factor Loading & Cronbach's alpha & Variance Explained \% \\
\hline HR (Factor 1) & 11 & $0.626-0.853$ & 0.921 & $21.82 \%$ \\
CA (Factor 2) & 7 & $0.669-0.918$ & 0.908 & $13.99 \%$ \\
SF (Factor 3) & 6 & $0.636-0.947$ & 0.914 & $10.09 \%$ \\
OP (Factor 4) & 7 & $0.634-0.746$ & 0.820 & $8.02 \%$ \\
HW (Factor 5) & 5 & $0.634-0.846$ & 0.722 & $6.14 \%$ \\
Total & 36 & & 0.792 & $60.06 \%$ \\
\hline
\end{tabular}

ISC, information system capabilities; HR, human resource; HW, hardware; SF, software; CA, competitive advantage; OP, organizational performance.

Confirmatory factor analysis (CFA) was used to ensure unidimensional of the identified constructs, that is, the existence of one dimension that underpins the set of metrics. The author tests the validity of this study through the convergent validity test. Awang and Hair et al. [136] and [133] said that to factor loading is the most important element to test and analyzed the convergent validity. According to Awang [136], the average variance extracted (AVE) should be 0.5 or higher to achieve validity, and the composite reliability $(\mathrm{CR})$ should $=0.6$. Table 4 summarizes the CFA result and shows that all constructs are reliable and meet the validity criteria.

Table 4 Confirmatory Factor Analysis Result

\begin{tabular}{ccccc}
\hline Construct & Items & Factor Loading & CR & AVE \\
\hline HR & 11 & $0.622-0.969$ & 0.935 & 0.58 \\
CA & 7 & $0.641-0.930$ & 0.927 & 0.65 \\
SF & 6 & $0.666-0.978$ & 0.917 & 0.65 \\
OP & 7 & $0.663-0.939$ & 0.905 & 0.58 \\
HW & 5 & $0.674-0.862$ & 0.863 & 0.56
\end{tabular}

ISC, information system capabilities; HR, human resource; HW, hardware; SF, software; CA, competitive advantage; OP, organizational performance.

\subsection{Hypotheses Testing}

The author used the PROCESS macro for SPSS version 3.5 to test the study hypotheses, a software designed to help researchers test relationships between variables that have a mediator or moderator (Hayes, 2018). Table 6 summarizes the details of the main hypotheses and sub-hypotheses. According to the criteria of Moore et al. (2013), the results of this study showed that H1 (Information system capabilities positively influence organizational performance) indicates that ISC has a weak influence on OP $(\mathrm{R} 2=0.2021, \mathrm{p}=0.000)$. H2 (Competitive advantage positively influence organizational performance) indicated that CA has significant and high positive influence on OP $(\mathrm{R} 2=0.812, \mathrm{p}=0.000)$. Similarly, H3 
Vol. 3, No. 2, June 2021

p-ISSN: 2656-5935 http://journal-isi.org/index.php/isi

e-ISSN: 2656-4882

(competitive advantage mediates the relationship between information system capabilities and organizational performance) showed that CA mediated the relationship between ISC and OP and has a strong and high positive influence $(\mathrm{R} 2=0.817, \mathrm{p}=0.0154)$. Hypotheses H3a, H3b and H3c showed that $\mathrm{CA}$ also mediated the relationship between HR, SF and HW and OP and had a strong and positive influence $(\mathrm{R} 2=0.858,0.817$ and $0.829, \mathrm{p}=0.000,0.0184$ and 0.000 , respectively). Therefore, the hypotheses and sub-hypotheses have yielded statistically significant results and are accepted.

Table 5 Result of Hypothesis Testing

\begin{tabular}{|c|c|c|c|c|c|c|c|c|}
\hline Hypothesis & Linkage & $R^{2}$ & F Test & $\begin{array}{l}\text { P- } \\
\text { value }\end{array}$ & $\begin{array}{l}\text { T- } \\
\text { Test }\end{array}$ & $\begin{array}{l}\text { P- } \\
\text { value }\end{array}$ & $\begin{array}{l}\text { B } \\
\text { Coefficient }\end{array}$ & $\begin{array}{l}\text { Hypotheses } \\
\text { Acceptance }\end{array}$ \\
\hline $\mathrm{H}_{1}$ & $-\rightarrow P$ & 0.222 & 66.2830 & 0.000 & 8.1414 & 0.000 & 0.2011 & Accepted \\
\hline $\mathbf{H}_{2}$ & $\mathrm{CA} \quad \rightarrow P$ & 0.812 & 1007.660 & 0.000 & 31.744 & 0.000 & 1.551 & Accepted \\
\hline $\mathbf{H}_{3}$ & ISC $\leadsto$ & $\mathrm{OP} \rightarrow 0.817$ & 517.5366 & 0.0154 & 2.441 & 0.000 & 0.0329 & Accepted \\
\hline $\mathrm{H}_{3} \mathrm{a}$ & $\mathrm{HR}-\triangle$ & $\stackrel{Q P}{\rightarrow} 0.858$ & 700.0186 & 0.000 & 8.6314 & 0.000 & 0.3847 & Accepted \\
\hline $\mathrm{H}_{3} \mathrm{~b}$ & $S F-A$ & $\stackrel{\mathrm{QP}}{\rightarrow} 0.817$ & 516.6753 & 0.0184 & 2.3740 & 0.000 & 0.2041 & Accepted \\
\hline $\mathrm{H}_{3} \mathrm{c}$ & $\mathrm{HW} \leadsto$ & $\mathrm{OP} \rightarrow 0.829$ & 562.7084 & 0.000 & 4.7881 & 0.000 & 0.2864 & Accepted \\
\hline
\end{tabular}

ISC, information system capabilities; HR, human resource; HW, hardware; SF, software; CA, competitive advantage; OP, organizational performance.

\section{DISCUSSIONS}

There is minimal research on the roles of the ISC and its effect on CA and OP on industrial corporations in Jordan. The current study therefore aimed to identify this problem by empirically analyzing the relationship between ISC and OP between managers and heads of departments working at Jordanian industrial corporations and evaluating how a CA mediates this relationship. The results showed that the relationship between ISC and OP is at $22.2 \%$, thus rendering it weak. This implies that industrial management must abandon the traditional frame of ISC. It is also related to the low and weak organizational culture towards ISC. Which means that poor technology, poor safety and training procedures, poor of $\mathrm{SF}$ that used in the corporations, inefficiency of $\mathrm{HR}$, and poor safety measures are also the most cited issues in industrial corporations [138]. Moreover, if the Jordanian industrial corporation need to be developed and competitive, they require from them to invest more in ISC [139]. Therefore, this study recommends that Jordanian industrial corporations must avoid weakness in management, and the shortage of facilities, using modern methods in training HR for SF and HW 
that used in industrial corporations to achieve a better OP. They must also adopt administrative procedures that dictate their goal, especially in the field ISC, which is reflected positively on the OP of industrial corporations if they implemented it in the right way [51], [63], [138], [140].

The results showed that $81.2 \%$ of the relationship between CA and OP. This means that CA is critical in the OP description. Therefore, managers of Jordanian industrial corporations should use the present results to establish strategies that deepen CA and boost OP. Managers can use the current findings to distinguish themselves in a competitive marketplace for industrial corporations. Managers of industrial corporations may try to increase OP by managing each dimension of core competence, such as mutual vision, collaboration and empowerment in the sense of industrial corporations, to remain competitive and obtain CA [141]-[144].

The findings of this research show that $\mathrm{CA}$ has a big influence and mediates 81.7 $\%$ of the interaction between the ISC and OP. This means that CA plays a very important role in strengthening the ISC and OP relationship. It is necessary that Jordanian industrial corporations recognize all relevant requirements for the effective execution of the strategy and must take due account of them to the implementation requirements of the chosen strategy to increase their OP [75], [88], [145]. Furthermore, the study results show that the CA mediated the relationship between HR, SF and HW and OP by $85.8 \%, 81.7 \%$ and $82.9 \%$ respectively, which is considered to have the highest influence of all ISCs for HR. This means that Jordanian industrial firms have training and development techniques that are considered to be an important factor in the business world, as they improve productivity, because it increases the efficiency and the effectiveness for both employees and the organization. By combining the needs of the company and the workers, CA has a distinct role in achieving an organizational objective. Moreover, the Jordanian industrial corporation have the consciousness to developing qualities in $\mathrm{HR}$ as a CA that will enable them to be more productive and thus to contribute more to organizational goal attainment and thus increase their OP. Also, they have the ability to develop their SF and HW to keep up with technological developments and gain a CA to enhance and improve their OP [80], [81], [91], [97], [114], [116], [117], [124], [146].

\section{CONCLUSION}

All types of organizations are increasingly using ISs, which must have a collection of capabilities to learn and use these instruments properly, constituting a framework that promotes and collaborates in achieving the objectives defined. IS gathers information, organizes individuals, systems, databases and devices that are used to provide routine information to help managers make efficient and effective decisions. In this scenario, both the individual and OP will be strengthened to play 
a vital role in achieving an organization's goals. It helps to ensure that real OP conforms to the organization's planned performance target by providing reliable and necessary details that can contribute to the achievement of organizational goals for successful decision-making. Jordanian industrial corporations need to create an effective atmosphere to direct ISC procedures to prompt OP and gain a CA. The findings of this study show that the ISC-derived CA is a crucial and fundamental variable that Jordanian industrial corporations can use. It also works to shed light on the issues and obligations that managers can perform in order to maximize the efficacy of OP, which in turn would have a positive influence on OP for the ISC. In terms of practical and managerial implications, the key findings suggest that if ISC is improved and becomes more reliable, Jordanian industrial corporations will gain, as this can lead to increased confidence of managers in the company and thus lead to CA. As a result, managers are more likely to put additional efforts into their work when their organization has a CA which has a positively impacts to increase the OP. There are some limitations and opportunities for future studies. First, the data for the current study was obtained from Jordanian industrial corporations, so it is not clear if in other countries the relationship between ISC, CA and OP is the same. Secondly, this study focuses on Jordanian industrial corporations only, which raises the question whether the relationships examined in this study will be different in other sectors.

\section{REFERENCES}

[1] Y. Agyabeng-Mensah, E. N. K. Ahenkorah, and E. Osei, "Impact of Logistics Information Technology on Organizational Performance: Mediating Role of Supply Chain Integration and Customer Satisfaction," J. Supply Chain Manag. Syst., vol. 8, no. 4, pp. 30-43, 2019.

[2] S. Ali and P. Green, "Effective information technology (IT) governance mechanisms: An IT outsourcing perspective," Inf. Syst. Front., vol. 14, no. 2, pp. 179-193, 2012.

[3] S. Harguem, "A conceptual framework on IT governance impact on organizational performance: A dynamic capability perspective," Acad. J. Interdiscip. Stud., vol. 10, no. 1, pp. 136-136, 2021.

[4] L. M. M. Zayed and R. Sinha, "Effectiveness of Accounting Information System in Manufacturing SMEs in Jordan - A Review of Literature," Int. J. Soc. Sci. Econ. Res., vol. 4, no. 2, pp. 819-825, 2019.

[5] P. Guan and J. Wu, "Effective Data Communication Based on Social Community in Social Opportunistic Networks," IEEE Access, vol. 7, pp. 12405-12414, 2019. 
[6] A. Gunasekaran, N. Subramanian, and T. Papadopoulos, "Information technology for competitive advantage within logistics and supply chains: A review," Transp. Res. Part E Logist. Transp. Rev., vol. 99, no. 2, pp. 14-33, 2017.

[7] L. Ma and E. Turban, "Strategic Information Systems for Competitive Advantage," in In: Decision Modelling and Information Systems. Operations Research/Computer Science Interfaces Series, vol. 26, Springer, Boston, MA, 2003, pp. $217-252$.

[8] W. Cascio and R. Montealegre, "How Technology Is Changing Work and Organizations," Annu. Rev. Organ. Psychol. Organ. Behav., vol. 3, pp. 349-375, 2016.

[9] P. J. Richard, T. M. Devinney, G. S. Yip, and G. Johnson, "Measuring organizational performance: Towards methodological best practice," J. Manag., vol. 35, no. 3, pp. 718-804, 2009.

[10] M. Yunis, A. Tarhini, and A. Kassar, "The role of ICT and innovation in enhancing organizational performance: The catalysing effect of corporate entrepreneurship," J. Bus. Res., vol. 88, pp. 344-356, 2018.

[11] K. Cameron, "Effects of Virtuous Leadership on Organizational Performance," in Positive Psychological Science, 2020, pp. 145-158.

[12] S. C. Selden and J. E. Sowa, "Testing a multi-dimensional model of organizational performance: Prospects and problems," J. Public Adm. Res. Theory, vol. 14, no. 3, pp. 395-416, 2004.

[13] J. Yoon and M.-G. Suh, "Determinants of organizational performance: some implications for top executive leadership in Korean firms," Asia Pac. Bus. Rev., vol. 25, no. 2, pp. 251-272, 2019.

[14] H. L. Boschken, "Organizational performance and multiple constituencies," Public Adm. Rev., vol. 54, no. 3, pp. 308-312, 1994.

[15] L. Lakhal, "Impact of quality on competitive advantage and organizational performance," J. Oper. Res. Soc., vol. 60, no. 5, pp. 637-645, 2009.

[16] M. H. McGivern and S. J. Tvorik, "Determinants of organizational performance," Manag. Decis., vol. 35, no. 6, pp. 417-435, 1997.

[17] S. K. Singh, T. F. Burgess, J. Heap, B. Almatrooshi, and S. Farouk, "Determinants of organizational performance: a proposed framework," Int. J. Product. Perform. Manag., vol. 65, no. 6, pp. 844-859, 2016.

[18] M. A. Nazri, N. A. Omar, and A. J. M. Hashim, "Corporate social responsibility and market orientation: An integrated approach towards organizational performance," J. Pengur. UKM J. Manag., vol. 52, pp. 121-132, 2018.

[19] T. Ramayah, N. Samat, and M.-C. Lo, "Market orientation, service quality and organizational performance in service organizations in Malaysia," AsiaPac. J. Bus. Adm., vol. 3, no. 1, pp. 8-27, 2011. 
[20] A. Anjomshoae, A. Hassan, N. Kunz, K. Y. Wong, and S. de Leeuw, “Toward a dynamic balanced scorecard model for humanitarian relief organizations' performance management," J. Humanit. Logist. Supply Chain Manag., vol. 7, no. 2, pp. 194-218, 2017.

[21] J. Broadbent and R. Laughlin, "Performance management systems: A conceptual model," Manag. Account. Res., vol. 20, no. 4, pp. 283-295, 2009.

[22] A. Ferreira and D. Otley, "The design and use of performance management systems: An extended framework for analysis," Manag. Account. Res., vol. 20, no. 4, pp. 263-282, 2009.

[23] I. Hristov, A. Appolloni, A. Chirico, and W. Cheng, "The role of the environmental dimension in the Performance Management System: A systematic review and conceptual framework," J. Clean. Prod., vol. 293, pp. 1$16,2021$.

[24] U. Johanson, R. Almqvist, and M. Skoog, "A conceptual framework for integrated performance management systems," J. Public Budg. Account. Financ. Manag., vol. 31, no. 3, 2019.

[25] D. Otley, "Performance management: a framework for management control systems research," Manag. Account. Res., vol. 10, no. 4, pp. 363-382, 1999.

[26] N. Venkatraman and V. Ramanujam, "Measurement of business performance in strategy research: A comparison of approaches," Acad. Manage. Rev., vol. 11, no. 4, pp. 801-814, 1986.

[27] C.-H. Kuei, C. N. Madu, and C. Lin, "The relationship between supply chain quality management practices and organizational performance," Int. J. Qual. Reliab. Manag., vol. 18, no. 8, pp. 864-872, 2001.

[28] J. Sutduean, A. Singsa, T. Sriyakul, and K. Jermsittiparsert, "Supply chain integration, enterprise resource planning, and organizational performance: The enterprise resource planning implementation approach," J. Comput. Theor. Nanosci., vol. 16, no. 7, pp. 2975-2981, 2019.

[29] M. Farrukh, C. W. Ying, and S. Mansori, "Organizational commitment: an empirical analysis of personality traits," J. Work-Appl. Manag., vol. 9, no. 1, pp. 18-34, 2017.

[30] S. S. Naquin and E. F. Holton, "The effects of personality, affectivity, and work commitment on motivation to improve work through learning," Hum. Resour. Dev. Q., vol. 13, no. 4, pp. 357-376, 2002.

[31] I. E. E. Salama, "The impact of knowledge management capability, organizational learning, and supply chain management practices on organizational performance," Bus. Manag. Rev., vol. 8, no. 5, pp. 37-51, 2017.

[32] J. G. Covin and M. P. Miles, "Corporate entrepreneurship and the pursuit of competitive advantage," Entrep. Theory Pract., vol. 23, no. 3, pp. 47-63, 1999. 
[33] A. S. Ogunsiji and W. K. Ladanu, "A theoretical study of performance measures in the strategic and corporate entrepreneurship of firms," Int. J. Life Sci. IJLS, vol. 1, no. 1, pp. 49-57, 2017.

[34] M. E. Porter, "From competitive advantage to corporate strategy," in Readings in strategic management, Springer, 1989, pp. 234-255.

[35] S. P. Saeidi, S. Sofian, P. Saeidi, S. P. Saeidi, and S. A. Saaeidi, "How does corporate social responsibility contribute to firm financial performance? The mediating role of competitive advantage, reputation, and customer satisfaction," J. Bus. Res., vol. 68, no. 2, pp. 341-350, 2015.

[36] P. L. Yadav, S. H. Han, and H. Kim, "Sustaining competitive advantage through corporate environmental performance," Bus. Strategy Environ., vol. 26, no. 3, pp. 345-357, 2017.

[37] N. Garg, "High performance work practices and organizational performancemediation analysis of explanatory theories," Int. J. Product. Perform. Manag., vol. 68, no. 4, pp. 797-816, 2019.

[38] L.-Y. Sun, S. Aryee, and K. S. Law, "High-performance human resource practices, citizenship behavior, and organizational performance: A relational perspective," Acad. Manage. J., vol. 50, no. 3, pp. 558-577, 2007.

[39] S. Hormio, "Can Corporations Have (Moral) Responsibility Regarding Climate Change Mitigation?," Ethics Policy Environ., vol. 20, no. 3, pp. 314 332, 2017.

[40] S. Natale, P. Bory, and G. Balbi, "The rise of corporational determinism: digital media corporations and narratives of media change," Crit. Stud. Media Commun., vol. 36, no. 4, pp. 323-338, 2019.

[41] Y. Wang, "Examination on philosophy-based management of contemporary Japanese corporations: philosophy, value orientation and performance," $J$. Bus. Ethics, vol. 85, no. 1, pp. 1-12, 2009.

[42] A. Kak, "Sustainable Competitive Advantage with Core Competence: A Review," Glob. J. Flex. Syst. Manag., vol. 3, no. 4, pp. 23-38, 2002.

[43] O. R. Mahdi, I. A. Nassar, and M. K. Almsafir, "Knowledge management processes and sustainable competitive advantage: An empirical examination in private universities," J. Bus. Res., vol. 94, pp. 320-334, 2019.

[44] N. Masroor and M. Asim, "SMEs in the Contemporary Era of Global Competition," Procedia Comput. Sci., vol. 158, pp. 632-641, 2019.

[45] Y. H. S. Al-Mamary, A. Shamsuddin, and A. Aziati, "The Role of Different Types of Information Systems in Business Organizations: A Review," Int. J. Res., vol. 1, no. 7, pp. 1279-1286, 2014.

[46] E. A. Al Hanini and Z. Al Oqqaily, "Does the Management Information System Causes Competitive Advantage for Banks working in Jordan?," Int. J. Econ. Financ. Issues, vol. 8, no. 6, p. 104, 2018. 
[47] A. J. Karim, "The Significance of Management Information Systems for Enhancing Strategic and Tactical Planning," J. Inf. Syst. Tecbnol. Manag., vol. 8, no. 2, pp. 459-470, 2011.

[48] A. Almasarwah, "Earnings Management and its Relationship with Corporate Governance Mechanisms in Jordanian Industrial Firms," Doctoral Thesis, Doctoral Thesis, Accounting Department, Loughborough University, 2015.

[49] A. R. El Dalabeeh and H. al-zeaud, "Accounting Information Systems and Their Role in the Measurement and Cost Thrifting in Public Shareholding Industrial Companies in Jordan," Int. J. Bus. Manag., vol. 7, no. 12, pp. 97106, 2012.

[50] F. Kasasbeh, "Impact of Corporate Governance on the Effectiveness of Accounting Information System in Jordanian Industrial Companies," Int. Bus. Res., vol. 10, no. 10, pp. 1-9, 2017.

[51] A.-H. Waseem, S. T. Alzurqan, and F. J. Al_Sufy, "The Effect of Corporate Governance on the Performance of Jordanian Industrial Companies: An empirical study on Amman Stock Exchange," Int. J. Humanit. Soc. Sci., vol. 1, no. 4, p. 15, 2011.

[52] F. J. Al_Sufy, H. I. M. Almbaideen, H. M. Al_abbadi, and M. H. Makhlouf, "Corporate Governance and Its Impact on the Quality of Accounting Information in the Industrial Community Shareholding Companies Listed in Amman Financial Market- Jordan," Int. J. Humanit. Soc. Sci., vol. 3, no. 5, pp. 184-195, 2013.

[53] A. S. Aydiner, E. Tatoglu, E. Bayraktar, and S. Zaim, "Information system capabilities and firm performance: Opening the black box through decisionmaking performance and business-process performance," Int. J. Inf. Manag., vol. 47, pp. 168-182, 2019.

[54] S. H. Abualoush, A. M. Obeidat, A. Tarhini, and A. Al-Badi, "The role of employees' empowerment as an intermediary variable between knowledge management and information systems on employees' performance," VINE J. Inf. Knowl. Manag. Syst., vol. 48, no. 2, pp. 217-237, 2018.

[55] L. Emeagwal and K. O. Ogbonmwan, "Mapping the perceived role of strategic human resource management practices in sustainable competitive advantage," Acad. Strateg. Manag. J., vol. 17, no. 2, pp. 1-19, 2018.

[56] A. I. Ganyam and J. A. Ivungu, "Effect of accounting information system on financial performance of firms: A review of literature," J. Bus. Manag., vol. 21, no. 5, pp. 39-49, 2019.

[57] M. Nassar, L. Warrad, and Y. A. Siam, "The implementation of enterprise resource planning system within Jordanian industrial sector," Int. Rev. Manag. Mark., vol. 7, no. 3, pp. 179-187, 2017. 
[58] M. A. A. Jarrah, L. Karadsheh, M. Naser, and S. Alhawari, "The influence of human resources management processes (HRMPs) to achieving sustainable competitive advantage," in Human performance technology: Concepts, methodologies, tools, and applications, IGI Global, 2019, pp. 1433-1451.

[59] A. Al-dmour, K. M. Al-Fawaz, R. Al-dmour, and N. M. Allozi, "Accounting information system and its role on business performance: A theoretical study," J. Manag. Strategy, vol. 8, no. 4, pp. 79-87, 2017.

[60] M. A. Ahmad and S. O. Al-Shbiel, "The effect of accounting information system on organizational performance in Jordanian industrial SMEs: The mediating role of knowledge management," Int. J. Bus. Soc. Sci., vol. 10, no. 3 , pp. 125-133, 2019.

[61] B. Sarwenda, "Intellectual capital, business performance, and competitive advantage: An empirical study for the pharmaceutical companies," QUALI TY Access Success J. Manag. Syst., vol. 21, no. 175, pp. 103-106, 2020.

[62] A. Bharadwaj, V. Sambamurthy, and R. Zmud, "IT capabilities: theoretical perspectives and empirical operationalization," in Proceedings of the 2 I th International Conference on Information Systems, Brisbane, Australia, Brisbane, Australia, 1999, pp. 378-385.

[63] A. S. Bharadwaj, S. G. Bharadwaj, and B. R. Konsynski, "Information technology effects on firm performance as measured by Tobin's q," Manag. Sci., vol. 45, no. 7, pp. 1008-1024, 2000.

[64] J. Braojos, J. Benitez, and J. Llorens, "How do social commerce-IT capabilities influence firm performance? Theory and empirical evidence," Inf. Manage, vol. 56, no. 2, pp. 155-171, 2019.

[65] S. M. Chege, D. Wang, and S. L. Suntu, "Impact of information technology innovation on firm performance in Kenya," Inf. Technol. Dev., vol. 26, no. 2, pp. 316-345, 2020.

[66] A. M. Gil-Padilla and T. F. Espino-Rodríguez, "Strategic value and resources and capabilities of the information systems area and their impact on organizational performance in the hotel sector," Tour. Rev., vol. 63, no. 3, pp. $21-47,2008$.

[67] P. Potjanajaruwit, "Competitive advantage effects on firm performance: A Case study of startups in Thailand," J. Int. Stud., vol. 11, no. 3, pp. 104-111, 2018.

[68] N. Rehman, S. Razaq, A. Farooq, N. M. Zohaib, and M. Nazri, "Information technology and firm performance: mediation role of absorptive capacity and corporate entrepreneurship in manufacturing SMEs," Technol. Anal. Strateg. Manag., vol. 32, no. 9, pp. 1049-1065, 2020.

[69] O. Turel, P. Liu, and C. Bart, "Board-level information technology governance effects on organizational performance: The roles of strategic 
alignment and authoritarian governance style," Inf. Syst. Manag., vol. 34, no. 2, pp. 117-136, 2017.

[70] R. Sabherwal, S. Sabherwal, T. Havakhor, and Z. Steelman, "How does strategic alignment affect firm performance? The roles of information technology investment and environmental uncertainty," MIS Q., vol. 43, no. 2, pp. 453-474, 2019.

[71] J. Benitez, A. Castillo, J. Llorens, and J. Braojos, "IT-enabled knowledge ambidexterity and innovation performance in small US firms: The moderator role of social media capability," Inf. Manage., vol. 55, no. 1, pp. 131-143, 2018.

[72] N. C. Cheptora, A. Osoro, and E. G. Musau, "The impact of information and communication technology on procurement performance in manufacturing firms in Kenya," Int. J. Acad. Res. Bus. Soc. Sci., vol. 8, no. 9, pp. 605-616, 2018.

[73] M. Franco and M. Garcia, "Drivers of ICT acceptance and implementation in micro-firms in the estate agent sector: influence on organizational performance," Inf. Technol. Dev., vol. 24, no. 4, pp. 658-680, 2018.

[74] J. Hyvönen, "Strategy, performance measurement techniques and information technology of the firm and their links to organizational performance," Manag. Account. Res., vol. 18, no. 3, pp. 343-366, 2007.

[75] S. Majeed, "The Impact of Competitive Advantage on Organizational Performance," Eur. J. Bus. Manag., vol. 3, no. 4, pp. 191-197, 2011.

[76] K. Saira, M. A. Zariyawati, and M. N. Annuar, "Information System and Firms' Performance: The Case of Malaysian Small Medium Enterprises," Int. Bus. Res., vol. 3, no. 4, pp. 28-35, 2010.

[77] S. N. Soudani, "The Usefulness of an Accounting Information System for Effective Organizational Performance," Int. J. Econ. Finance, vol. 4, no. 5, pp. 136-145, 2012.

[78] H. Ma, "Competitive Advantage and Firm Performance," Compet. Rev. Int. Bus. J., vol. 10, no. 2, pp. 15-32, 2000.

[79] N. A. Morgan, A. Kaleka, and C. S. Katsikeas, "Antecedents of Export Venture Performance: A Theoretical Model and Empirical Assessment on JSTOR," J. Mark., vol. 68, no. 1, pp. 90-108, 2004.

[80] J. W. Ong, H. Ismail, and P. F. Yeap, "Competitive advantage and firm performance: the moderating effect of industry forces," Int. J. Bus. Perform. Manag., vol. 19, no. 4, pp. 385-407, 2018.

[81] P. Potjanajaruwit, "Competitive advantage effects on firm performance: A Case study of startups in Thailand," J. Int. Stud., vol. 11, no. 3, pp. 104-111, 2018. 
[82] R. C. Rose, H. Abdullah, and A. I. Ismad, "A Review on the Relationship between Organizational Resources, Competitive Advantage and Performance," J. Int. Soc. Res., vol. 3, no. 11, pp. 488-498, 2010.

[83] C. Sigalas, "Competitive advantage: the known unknown concept," Manag. Decis., vol. 53, no. 9, pp. 2004-2016, 2015.

[84] S. Z. Khan, Q. Yang, and A. Waheed, "Investment in intangible resources and capabilities spurs sustainable competitive advantage and firm performance," Corp. Soc. Responsib. Environ. Manag., vol. 26, no. 2, pp. $285-$ 295, 2019.

[85] C. R. Raduan and H. Abdullah, "Management, Strategic Management Theories and the Linkage with Organizational Competitive Advantage from the Resource-Based View," Eur. J. Soc. Sci., vol. 11, pp. 402-417, 2009.

[86] R. Allen and M. Helms, "Linking Strategic Practices and Organizational Performance to Porter's Generic Strategies," Bus. Process Manag. J., vol. 12, no. 4, pp. 433-454, 2006.

[87] J. Ferreira, A. Coelho, and L. Moutinho, "Dynamic capabilities, creativity and innovation capability and their impact on competitive advantage and firm performance: The moderating role of entrepreneurial orientation," Tecbnovation, vol. 92-93, pp. 1-18, 2020.

[88] L. Teeratansirikool, S. Siengthai, Y. Badir, and C. Charoenngam, "Competitive strategies and firm performance: The mediating role of performance measurement," Int. J. Product. Perform. Manag., vol. 63, no. 1 \& 2, pp. 168-184, 2013.

[89] W. Baker and J. Sinkula, "Market Orientation, Learning Orientation and Product Innovation: Delving into the Organization's Black Box," J. Mark.Focus. Manag., vol. 5, no. 1, pp. 5-23, 2002.

[90] D. Escandón-Barbosa and A. Hurtado-Ayala, "Effects of market orientation and learning orientation on organisational performance," Glob. Bus. Econ. Rev., vol. 22, no. 3, pp. 249-269, 2020.

[91] L. Breznik, "Can Information Technology be a Source of Competitive Advantage?," Econ. Bus. Rev. Cent. South-East. Eur., vol. 14, no. 3, pp. 251269, 2012.

[92] T. Dewett and G. Jones, "The Role of Information Technology in the Organization: A Review, Model, and Assessment," J. Manag., vol. 27, no. 3, pp. 313-346, 2001.

[93] P. Soto-Acosta, S. Popa, and I. Martinez-Conesa, "Information technology, knowledge management and environmental dynamism as drivers of innovation ambidexterity: a study in SMEs," J. Knowl. Manag., vol. 22, no. 4, pp. 824-849, 2018. 
[94] C.-N. Chiu and C.-L. Yang, "Competitive advantage and simultaneous mutual influences between information technology adoption and service innovation: Moderating effects of environmental factors," Struct. Change Econ. Dyn., vol. 49, pp. 192-205, 2019.

[95] A. Tarute and R. Gatautis, "ICT Impact on SMEs Performance," Procedia Soc. Behav. Sci., vol. 110, pp. 1218-1225, 2014.

[96] D. B. Minbaeva, "Building Credible Human Capital Analytics for Organizational Competitive Advantage," Hum. Resour. Manage., vol. 57, no. 3, pp. 701-713, 2018, doi: 10.1002/hrm.21848.

[97] H. H. Hamadamin and T. Atan, "The impact of strategic human resource management practices on competitive advantage sustainability: The mediation of human capital development and employee commitment," Sustainability, vol. 11, no. 20, p. 5782, 2019.

[98] P. M. Wright and G. C. McMahan, "Exploring Human Capital: Putting Human Back into Strategic Human Resource Management," Hum. Resour. Manag. J., vol. 21, no. 2, pp. 93-104, 2011.

[99] M. A. Findiklı, U. Yozgat, and Y. Rofcanin, "Examining organizational innovation and knowledge management capacity the central role of strategic human resources practices (SHRPs)," Procedia Soc Behav Sci, no. 181, pp. $377-$ 387, 2015.

[100] C. R. Greer, Strategic Human Resource Management: A General Managerial Approach, 2nd ed. Prentice Hall: Upper Saddle River, NJ, USA, 2001.

[101] C. R. Greer, Strategic buman resource management, Special edition. Prentice Hall: Upper Saddle River, NJ, USA, 2019.

[102] Huang and T. C. Huang, "Relationship between strategic human resource management and firm performance," Int J Manpow, vol. 26, pp. 434-449, 2005.

[103] W. Kuncoro and W. O. Suriani, "Achieving sustainable competitive advantage through product innovation and market driving," Asia Pac Manag Rev, vol. 23, pp. 186-192, 2018.

[104] O. R. Mahdi and M. K. Almsafir, "The role of strategic leadership in building sustainable competitive advantage in the academic environment," Procedia Soc Behav Sci, vol. 126, pp. 289-296, 2018.

[105] J. Covin and G. Lumpkin, "Entrepreneurial orientation theory and research: Reflection on a needed," Constr. Entrep Theory Pr., vol. 35, pp. 855872, 2011.

[106] P. Ball, "Dynamic Modelling for Supply Chain Management: Dealing with Front-End, Back-End and Integration Issues, by Adolfo Crespo Marquez," Prod. Plan. Control Manag. Oper., vol. 24, no. 1, pp. 141-142, 2013. 
[107] J. Jamshi and C. Ganeshkumar, "Causal Linkage Among Business Analytics, Supply Chain Performance, Firm Performance and Competitive Advantage.," Parikalpana KIIT J. Manag., vol. 13, no. 2, pp. 29-36, 2017.

[108] A. Nozari and Maryam Mjjdehi, "The Impact of Supply Chain Management Strategy on Organizational Performance Through Total Just in Time (T-JIT) by Using Approach of Structural Equation Model," J. Eng. Appl. Sci., vol. 11, pp. 2834-2840, 2016.

[109] S. Chaudhry, "Managing employee attitude for a successful information system implementation: a change management perspective," J. Int. Tecbnol. Inf. Manag., vol. 27, no. 1, pp. 57-90, 2018.

[110] H. C. Lucas and R. H. Smith, Implementation: The Key to Successful Information Systems. Columbia University Press, New York, USA, 1981, p. 208.

[111] S. H. Kim, S. Y. Jang, and K. H. Yang, "Analysis of the determinants of software-as-a-service adoption in small businesses: Risks, benefits, and organizational and environmental factors," J. Small Bus. Manag., vol. 55, no. 2, pp. 303-325, 2017.

[112] H. Stadtler and C. Kilger, Supply Chain Management and Advanced Planning: Concepts, Models, Software and Case Studies, 3rd ed. Berlin: Springer, 2008, p. 503.

[113] M. Bevilacqua, F. E. Ciarapica, and C. Paciarotti, "Implementing lean information management: the case study of an automotive company," J. Prod. Plan. Control, vol. 26, no. 10, pp. 753-768, 2015.

[114] G. D. Bhatt and V. Grover, "Types of Information Technology Capabilities and Their Role in Competitive Advantage: An Empirical Study.," J. Manag. Inf. Syst., vol. 22, no. 3, pp. 253-277, 2005.

[115] P. Mikalef and A. Pateli, "Information technology-enabled dynamic capabilities and their indirect effect on competitive performance: Findings from PLS-SEM and fsQCA," J. Bus. Res., vol. 70, pp. 1-16, 2017.

[116] H.-C. Chae, C. E. Koh, and K. O. Park, "Information technology capability and firm performance: Role of industry," Inf. Manage, vol. 55, no. 5, pp. 525-546, 2018.

[117] R. Santhanam and E. Hartono, "Issues in Linking Information Technology Capability to Firm Performance," Manag. Inf. Syst. Q., vol. 27, no. 1, pp. 125-153, 2003.

[118] J. H. Han and H.-M. Kim, "The role of information technology use for increasing consumer informedness in cross-border electronic commerce: an empirical study," Electron. Commer. Res. Appl., vol. 34, pp. 1-16, 2019.

[119] B. Jun and B.-G. Kang, "Organizational Characteristics and Electronic Commerce Utilization in Korea," J. Glob. Bus. Technol., vol. 5, no. 1, pp. 1-17, 2009. 
[120] M. L. Fang, S. L. Canham, L. Battersby, J. Sixsmith, M. Wada, and A. Sixsmith, "Exploring privilege in the digital divide: implications for theory, policy, and practice," The Gerontologist, vol. 59, no. 1, pp. 1-15, 2019.

[121] C. Forman, "The corporate digital divide: Determinants of Internet adoption," Manag. Sci., vol. 51, no. 4, pp. 641-654, 2005.

[122] P. O. H. Putra and H. B. Santoso, "Contextual factors and performance impact of e-business use in Indonesian small and medium enterprises (SMEs)," Heliyon, vol. 6, no. 3, pp. 1-10, 2020.

[123] D.-M. Lee, H.-S. Ahn, and H.-J. Kim, "A Comparative Analysis on the eBusiness Adoption Factors and Performance in Large and Small Companies," J. Inf. Syst., vol. 17, no. 4, pp. 157-180, 2008.

[124] S. Mupemhi and A. Muposhi, "Organisational Factors Influencing Ebusiness Adoption in Zimbabwe's Manufacturing Sector," J. Econ. Behav. Stud., vol. 10, no. 2 (J), pp. 176-187, 2018.

[125] S. Wang and W. Cheung, "E-Business Adoption by Travel Agencies: Prime Candidates for Mobile e-Business," Int. J. Electron. Commer., vol. 8, no. 3, pp. 43-63, 2004.

[126] Y. J. Kim, H. Kang, G. Lawrence Sanders, and S.-Y. Tom Lee, "Differential effects of IT investments: Complementarity and effect of GDP level," Int. J. Inf. Manag., vol. 28, no. 6, pp. 508-516, 2008.

[127] T. S. Teo, "Organizational characteristics, modes of internet adoption and their impact: a Singapore perspective," J. Glob. Inf. Manag. JGIM, vol. 15, no. 2, pp. 91-117, 2007.

[128] H. Lu, P. Pishdad-Bozorgi, G. Wang, Y. Xue, and D. Tan, "ICT implementation of small-and medium-sized construction enterprises: organizational characteristics, driving forces, and value perceptions," Sustainability, vol. 11, no. 12, p. 3441, 2019.

[129] E. González-González and S. Nogués, "Long-term differential effects of transport infrastructure investment in rural areas," Transp. Res. Part Policy Pract., vol. 125, pp. 234-247, 2019.

[130] R. Silva, O. Gerwe, and M. Becerra, "Corporate brand and hotel performance: A resource-based perspective," J. Bus. Res., vol. 79, pp. 23-30, 2017.

[131] S.-M. Huang, C.-S. Ou, C.-M. Chen, and B. Lin, "An empirical study of relationship between IT investment and firm performance: A resource-based perspective," Eur. J. Oper. Res., vol. 173, no. 3, pp. 984-999, 2006.

[132] M. Wade and J. Hulland, "The Resource-Based View and Information Systems Research: Review, Extension, and Suggestions for Future Research," MIS Q., vol. 28, no. 1, pp. 107-142, 2004. 
[133] J. F. Hair, W. C. Black, B. J. Babin, and R. E. Anderson, Multivariate Data Analysis, 7th ed. Harlow, UK: Pearson Education Limited, 2014.

[134] T. R. Hinkin, "A brief tutorial on the development of measures for use in survey questionnaires," Organ. Res. Methods, vol. 2, no. 1, pp. 104-121, 1998.

[135] H. F. Kaiser, “An Index of Factorial Simplicity,” Psychometrika, vol. 39, no. 1, pp. 31-36, 1974.

[136] Z. Awang, SEM Structural Equation Modeling Using AMOS Graphic. Shah Alam, Malaysia: Universiti Teknologi MARA Publication Centre (UPENA), 2012.

[137] D. S. Moore, W. I. Notz, and M. A. Fligner, The Basic Practice of Statistics, 6th ed. New York: W. H. Freeman and Company, 2013, p. 989.

[138] A. K. Saddam, "A Study on The Relationship Between Perceived Strategic Human Resource Management and Organization Performance with Organization Citizenship Behavior as The Mediator," Doctoral Thesis, Faculty of Management, Universiti Teknologi Malaysia, 2017.

[139] S. E. Hendrix, "Institutional Capacity Building and Legal Reform in Iraq: Toward Innovation and Public Administration Modernization," Law Dev. Rev., vol. 6, no. 1, pp. 225-253, 2013.

[140] L. Tashtoush and S. Z. Eyupoglu, "The Relationship between Human Resource Management Practices and Organisational Citizenship Behaviour," South Afr. J. Bus. Manag., vol. 51, no. 1, pp. 1-11, 2020.

[141] S. Agha, L. Alrubaiee, and M. Jamhour, "Effect of Core Competence on Competitive Advantage and Organizational Performance," Int. J. Bus. Manag., vol. 7, no. 1, p. p192, 2011.

[142] R. J. Calantone, S. T. Cavusgil, and Y. Zhao, "Learning orientation, firm innovation capability, and firm performance," Ind. Mark. Manag., vol. 31, no. 6, pp. 515-524, 2002.

[143] S. C. Srivastava, "Managing Core Competence of the Organization," Vikalpa, vol. 30, no. 4, pp. 49-64, 2005.

[144] U. Udriyah, J. Tham, and S. Azam, "The effects of market orientation and innovation on competitive advantage and business performance of textile SMEs," Manag. Sci. Lett., vol. 9, no. 9, pp. 1419-1428, 2019.

[145] M. Salman, S. A. Ganie, and I. Saleem, "Employee Competencies as Predictors of Organizational Performance: A Study of Public and Private Sector Banks," Manag. Labour Stud., vol. 45, no. 4, pp. 416-432, 2020.

[146] A. K. Paul and R. N. Anantharaman, "Influence of HRM Practices on Organizational Commitment: A Study Among Software Professionals in India," Hum. Resour. Dev. Q., vol. 15, no. 1, pp. 77-88, 2004. 